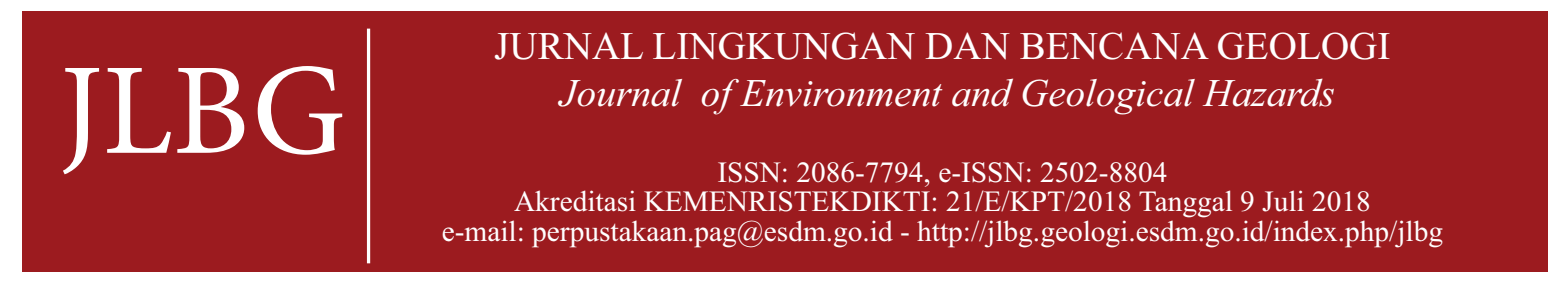

\title{
Groundwater Fluctuation Simulation of Pagelaran Landslide, Cianjur, Indonesia
}

\section{Simulasi Fluktuasi Air Tanah pada Gerakan Tanah di Pagelaran, Cianjur, Indonesia}

\author{
Twin. H. W. Kristyanto ${ }^{1,2}$, Asriza $^{1}$, R. Syahputra ${ }^{1}$, Join Wan C. Sigalingging ${ }^{3}$, and Tito L. Indra ${ }^{4}$ \\ ${ }^{1}$ Program Studi Geologi, FMIPA UI, Universitas Indonesia \\ Kampus UI Depok, Kota Depok, 16424, Indonesia \\ ${ }^{2}$ Institute of Applied Geology, National Central University \\ No. 300, Zhongda Rd., Zhongli District, Taoyuan City 32001, Taiwan \\ ${ }^{3}$ Division of database Center, Meteorological, Climatological, and Geophysical Agency, Indonesia \\ Jalan Angkasa I, No.2 Kemayoran, Jakarta Pusat 10720 \\ No. 300, Zhongda Rd., Zhongli District, Taoyuan City 32001, Taiwan \\ ${ }^{4}$ Program StudiGeofisika, FMIPA UI, Universitas Indonesia \\ Kampus UI Depok, Kota Depok, 16424, Indonesia \\ e-mail: twin.hosea@sci.ui.ac.id \\ Naskah diterima 02 September 2018, selesai direvisi 25 November 2019, dan disetujui 05 April 2020
}

\begin{abstract}
Pagelaran is one of area in southern part of Cianjur. This area has high susceptibility to landslide. One of landslide in Pagelaran, which happened on December 2014, destroyed 13 houses and damaged vital road along $200 \mathrm{~m}$. A year later, it started to conduct observation regarding the slope. The research aimed to know the role of groundwater level fluctuation in Pagelaran Landslide. The geometry of slope and its slip surface were determined using Electrical Resistivity Tomography. The actual groundwater level was determined by measuring it from surrounding wells. Parameters angle of friction, cohesion, and unit weight were obtained from laboratory tests toward undisturbed soil samples. These data were used for analyzing the actual slope stability condition. Then it was conducted the simulation of slope stability in accordance with fluctuations of groundwater level. The simulation was done by raising the groundwater level with range of $0.5 \mathrm{~m}$. The results showed that the actual slope stability was in critical condition with the value of safety factor 1.044. It also showed that slope stability waned as rising of groundwater level. The value of safety factor was reduced by an average of 0.034 in each $0.5 \mathrm{~m}$ up of groundwater level until it became failure $(\mathrm{FS}<1)$ when the groundwater level was $0.95 \mathrm{~m}$ above the actual position. Therefore, it can be concluded that the position of groundwater level played a role toward the stability of slope in Pagelaran. The rising $0.5 \mathrm{~m}$ of groundwater level position will reduce the slope safety factor by 0.034 . The slope will become failure if the position of groundwater level rises by 0.95 meter from the actual position. To prevent the rising of groundwater level in rainy season, which can trigger landslide, it can be attached pipes along the slope body to flow the groundwater through it.
\end{abstract}

Keywords: Groundwater fluctuation, landslide, slope stability, safety factor

\section{ABSTRAK}

Pagelaran merupakan salah satu area di wilayah selatan Cianjur. Area ini memiliki kerentanan yang tinggi terhadap bahaya gerakan tanah. Salah satu gerakan tanah di Pagelaran, yang terjadi pada Desember 2014, menghancurkan 13 rumah dan merusak jalan desa sepanjang 200 meter. Satu tahun kemudian, dilakukan penelitian terhadap lereng yang mengalami gerakan tanah tersebut. Penelitian ini bertujuan untuk mengetahui peran fluktuasi muka air tanah pada kejadian gerakan tanah Pagelaran. Geometri gerakan tanah dan bidang gelincir lerengnya ditentukan menggunakan Electrical Resistivity Tomography. Tinggi muka airtanah aktual ditentukan melalui pengukuran langsung pada beberapa sumur warga. Parameter kohesi, dan bobot satuan ditentukan melalui pengujian laboratorium terhadap sampel tanah tak terganggu. Data tersebut digunakan untuk menganalisis kondisi kestabilan lereng aktual. Simulasi kestabilan lereng dilakukan sesuai dengan fluktuasi muka airtanah dengan rentang kenaikan 0.5 meter. Hasil penelitian 
menunjukkan bahwa kestabilan lereng aktual berada pada kondisi kritis dengan faktor keamanan 1.044. Hasil ini juga menunjukkan bahwa kestabilan lereng menurun seiring dengan naiknya muka airtanah. Nilai faktor keamanan berkurang rata-rata 0.034 setiap kenaikan muka airtanah sebesar $0.5 \mathrm{~m}$, hingga mengalami kelongsoran (FK $<1)$ pada saat muka airtanah berada pada kedalaman $0.95 \mathrm{~m}$ di atas posisi aktual. Dapat disimpulkan bahwa posisi muka airtanah memerankan(memainkan) peran terhadap kestabilan lereng di Pagelaran. Kenaikan 0.5 m muka airtanah akan mengurangi kestabilan lereng sebesar 0.034. Lereng akan mengalami kelongsoran jika posisi muka airtanah naik hingga $0.95 \mathrm{~m}$ dari posisi awal. Untuk mencegah kenaikan muka airtanah pada musim penghujan, yang dapat memicu terjadinya gerakan tanah, maka dapat dipasang pipa di sepanjang tubuh lereng untuk mengalirkan airtanah melalui pipa tersebut.

Kata kunci: Fluktuasi airtanah, gerakan tanah, kestabilan lereng, faktor keamanan

\section{INTRODUCTION}

Landslide is one of the geological disasters that can cause devastations in an area. It can be induced by a disturbance of stability, due to climatic factors, geological aspects (lithology and tectonics), and could be worsened by human influence, such as deforestation which decreases the soil cohesion (Purnamasari and Madlazim, 2015). Landslide brings many lost both in souls and in materials. It has brought many efforts and analysis, in various kinds of region, to be tried to decrease the annual number of the landslide occurrences. They are in the forms of landslide susceptibility mapping or specific site investigation to measure the stability of the slope.

In December 2014, a landslide occurred in one village of Pagelaran District, Cianjur Regency, West Java Province. This land movement destroyed 13 houses and collapsed the road along $200 \mathrm{~m}$. Based on the Landslide Forecasting Map of Cianjur Regency, Pagelaran is one of the hot spots of landslide potential. It means that the location is prone to a landslide if triggered by rainfall, earthquake, landuse change, or other triggering factors (Asriza et al, 2017; Salam et al., 2017; Ramadhika et al., 2018; Anonymous, 2018).

Rainfall intensity in an area can be the main triggering factors for landslide occurrence, especially in tropical regions (Guzzetti et al., 2008; Bui et al., 2016). This condition can take effect on groundwater fluctuation. It can influence the slope stability, either natural slope or man-made one (Alimohammadlou et al., 2014). Therefore, this research aims to know the role of groundwater level rising in landslide occurrence at research location. It hopes that this research can elevate the awareness toward subsequent landslides that may occur due to groundwater level rising when there a heavy rainfall.

Figure 1(a) shows the morphology of research area. This photograph was taken in orientation of Southwest-Northeast. The elevation of research area is in the range of $\pm 440-475$ MASL and the slope is in the range of 150 to 200 or about $\pm 25-40 \%$. The slope which collapsed is in the highest elevation in research area that is $474 \mathrm{~m}$ above sea level. Geomorphological profile in research area that generated from digital elevation model can be seen on Figure 1(b). It uses contour interval 2 meters.

Geological structures that develop in research area are in the forms of: faults, folds, and joints. They can be found in Oligo-Miocene rocks. Faults in research area consist of strike slip faults with general orientation of North Northwest - South Southeast and normal fault with orientation North-South and East-West. Fold patterns that appear in research area are Southwest-Northeast and East-West anticline and Southwest-Northeast syncline. The ridge and valley also show lineament with orientation Northwest-Southeast and Southwest-Northeast and it involves Quaternary rocks. Figure 2 shows the geological map of research area (Koesmono et al., 1996).

Bedrocks that formed the slope, based on Geological Map of Sindangbarang and Bandarwaru (Koesmono et al., 1996), are consisting of rock of Koleberes Formation and Bentang Formation. Koleberes Formation (Tmk) is consisting 


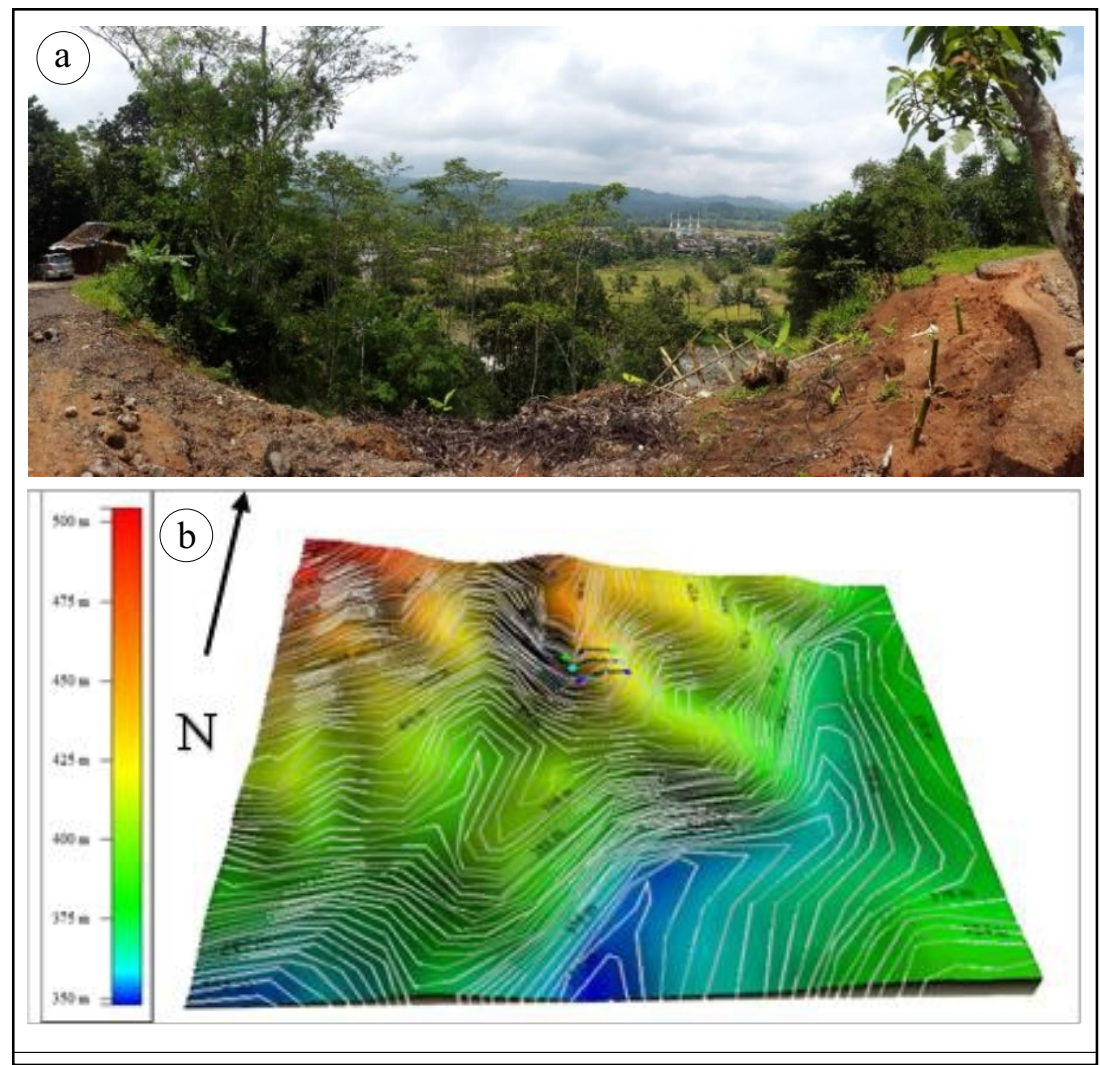

Figure 1. Geomorphology of research area (a) and geomorphological profile of research area (b) (not scaled).

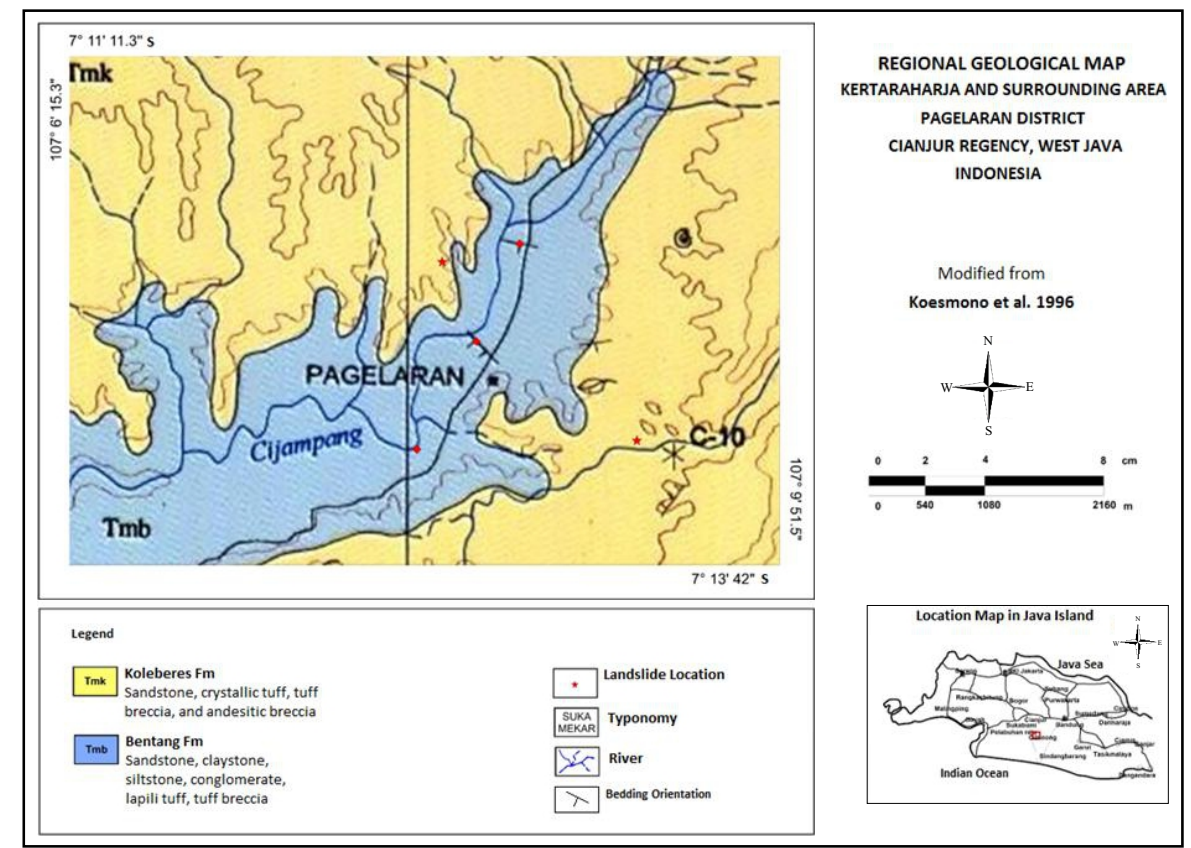

Figure 2. Geological map of research area (Koesmono et al., 1996).

of laminated tuff sandstone, crystal tuff, tuff breccia, and andesitic breccia. Bentang Formation (Tmb) formed the lower part of the slope. It consists of laminated tuff sandstone, crystallic tuff, globigerina claystone, siltstone, andesitic breccia, conglomerate, and lapilli tuff. 


\section{METHOD}

Geophysical methods can be used to know the underground condition of an area. Therefore, these methods are able to be used for determining the slip surface of a landslide (McCann and Foster, 1990). One of geophysical methods that can be used is Electrical Resistivity Tomography (ERT). Resistivity method is good to be used for identifying the slip surface because it can predict electricity properties of a soil/rock layer, which are influenced by soil type, porosity, permeability, and water content. Porosity will influence the value of resistivity of soil or rocks. The more the water content, the resistivity value will be low, and vice versa resistivity will be even greater if the fluid content in rocks is reduced (Telford et al., 1990). The difference of resistivity value shows the difference of lithological types and their permeability. The boundary between permeable and impermeable layers can be interpreted as slip surface (Jongman and Garambois, 2007).

We conducted geotechnical drilling to acquire the undisturbed soil samples (Figure 3). The samples were tested in the soil mechanics laboratory to gain physical and mechanical properties of soil. The results were used for slope stability analysis and simulation of the role of water table fluctuation toward slope stability.

Slope stability analysis was conducted using Fellenius Method (Fellenius, 1939 in Liu et al., 2017). We used this method to analyze the slope stability in soil with a circular slip surface. Fellenius method assumes in the calculation to involve inter-slice normal force or vertical approach, but it ignores inter-slice shear force or shear force between slices (assuming shear force resultant zero). It only considers the vertical force; thus normal force is gotten by sum all vertical forces. Therefore, Fellenius method can be used for calculating the safety factor in circular slip surface landslide.

In the slope that influenced by groundwater, the formula of safety factor (FS) is:

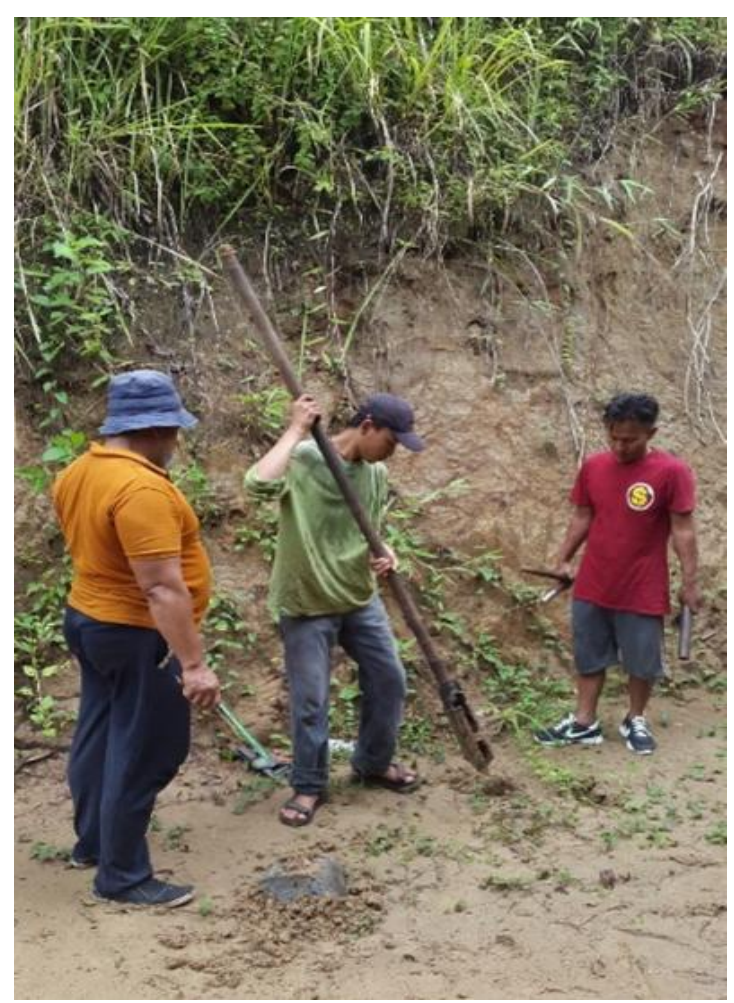

Figure 3. Geotechnical drilling at the foot of slope.

$$
F S=\frac{c L+\tan \tan \Phi \sum\left(W_{i} \operatorname{Cos} a_{i}-\mu_{i} l_{i}\right)}{\sum W_{i} \operatorname{Cos} a_{i}}
$$

While for slope which ignore the effect of groundwater, the formula of safety factor (FS) is:

$$
F S \frac{c L+\tan \tan \Phi \sum\left(W_{i} \operatorname{Cos} a_{i}\right)}{\sum\left(W_{i} \operatorname{Cos} a_{i}\right)}
$$

Which:

$\mathrm{c}=$ cohesion $\left(\mathrm{kN} / \mathrm{m}^{2}\right)$

$\phi=$ internal friction angle (degree)

$\alpha=$ the angle of each slice (degree)

$\mu=$ pore pressure $\left(\mathrm{kN} / \mathrm{m}^{2}\right)$

$1=$ the length of slip surface in each slice $(\mathrm{m})$

$\mathrm{L}=$ sum of the length of slip surface (m)

$\left(\mu_{\mathrm{i}}\right)\left(1_{\mathrm{i}}\right)=$ pore pressure in each slice $(\mathrm{kN} / \mathrm{m})$

$\mathrm{W}=$ the area of slice $\left(\mathrm{m}^{2}\right) \mathrm{X}$ unit weight of soil $\left(\gamma, \mathrm{kN} / \mathrm{m}^{3}\right)$

Slope stability analysis and simulation of water table fluctuation were conducted using Geoslope 2007 (https://www.geoslope.com/). 


\section{RESULTS AND DISCUSSION}

The boundary between medium resistivity and low resistivity was interpreted as slip surface, which in the depth of 3-5 m from surface. From slope profile that was generated from 3D resistivity method, it can be interpreted that the slope has two potential slip surface (Figure 4.). The first slip surface is in the foot of the slope, and the second one is in the top of the slope. The interpreted slip surfaces are also confirmed by $2 \mathrm{D}$ resistivity profile, which shows resistivity contrast in the depth of 3-5 meters.

Based on soil mechanics laboratory tests, the soil type in the top of the slope is clay high plasticity $(\mathrm{CH})$, while the soil type in the foot of the slope is silt high plasticity (MH). It is in line with the result of $2 \mathrm{D}$ resistivity measurement, which $\mathrm{CH}$ and $\mathrm{MH}$ are classified as impermeable soil. It shows various values of resistivity in the range of moderate to high. On the other hand, the value with low resistivity is own by SC-ML (clayey sand interfingering with low plasticity silt soil) layer. It is in line with the results of 2D resistivity measurement, which shows low resistivity, then it is classified as a permeable layer in which water can flow through it.

Groundwater level measurement was conducted in February 2016 from dug wells and seepage in the wall of a slope. We found the groundwater level is about $1.5 \mathrm{~m}$ from the soil surface.

The results of soil mechanics laboratory tests are shown in Table 1 and 2. They are used as parameters for slope stability analysis.

We infer the lithological difference from 2D resistivity measurement confirmed by laboratory test results. The slope profile (Figure 4) shows that the slope has two potential slip surfaces. The slope stability analysis shows that the actual safety factor of the slope is 1.044 for the top slip surface, which means the slope is in critical condition (Bowles, 1989). The top slip surface is located in the boundary between $\mathrm{CH}$ soil and SC-ML soil. This analysis also shows that the actual slope stability factor for the footslope is 1.052 , which also means that the slope is in critical condition. The foot slip surface is located in the boundary between MH soil and SC-ML
Table 1. Physical and mechanical properties of soil in the foot of slope

\begin{tabular}{|c|c|c|c|c|}
\hline $\begin{array}{l}\text { Depth } \\
\text { (m) }\end{array}$ & $\begin{array}{c}\gamma_{\text {wet }} \\
\left(\mathbf{k N} / \mathbf{m}^{3}\right)\end{array}$ & $\begin{array}{c}c \\
\left(k N / m^{2}\right)\end{array}$ & $\varphi\left({ }^{\circ}\right)$ & $\begin{array}{c}\text { Soil } \\
\text { Type } \\
\text { (USCS) }\end{array}$ \\
\hline $0-0.5$ & 16.255 & 25.989 & 13.4 & $\mathrm{MH}$ \\
\hline $0.5-1.0$ & 16.378 & 22.556 & 13.375 & $\mathrm{MH}$ \\
\hline $1.0-1.5$ & 15.789 & 31.382 & 17.8 & $\mathrm{MH}$ \\
\hline $1.5-2.0$ & 16.378 & 24.518 & 11.4 & MH \\
\hline $2.0-2.5$ & 16.255 & 25.989 & 10.9 & MH \\
\hline
\end{tabular}

Table 2. Physical and mechanical properties of soil in the top of slope

\begin{tabular}{ccccc}
\hline $\begin{array}{c}\text { Depth } \\
(\mathbf{m})\end{array}$ & $\begin{array}{c}\boldsymbol{\gamma}_{\text {wet }} \\
\left(\mathbf{k N} / \mathbf{m}^{3}\right)\end{array}$ & $\begin{array}{c}\mathbf{c} \\
\left(\mathbf{k N} / \mathbf{m}^{2}\right)\end{array}$ & $\left.\boldsymbol{\varphi (}{ }^{\circ}\right)$ & $\begin{array}{c}\text { Soil Type } \\
(\mathbf{U S C S})\end{array}$ \\
\hline $0-0.5$ & 16.255 & 25.989 & 13.4 & $\mathrm{MH}$ \\
$0.5-1.0$ & 16.378 & 22.556 & 13.375 & $\mathrm{MH}$ \\
$1.0-1.5$ & 15.789 & 31.382 & 17.8 & $\mathrm{MH}$ \\
$1.5-2.0$ & 16.378 & 24.518 & 11.4 & $\mathrm{MH}$ \\
$2.0-2.5$ & 16.255 & 25.989 & 10.9 & $\mathrm{MH}$ \\
\hline
\end{tabular}

soil. The position of slip surface and the value of slope stability analysis are shown in figure 5 .

We simulated the sensitivity of groundwater table change with slope stability. We raised the groundwater level $0.5 \mathrm{~m}$ from the actual depth (i.e. $1.5 \mathrm{~m}$ below surface). The existing slope stability reaches in critical condition with a safety factor of 1.044, for the slip surface at the top of the slope, and 1.052 for the slip surface at the foot one. The results show raising groundwater level will not impact the FS of the slope for slip surface at the foot of the slope (Slip surface IFigure 4). It is because the actual condition of the slope has reached its most pessimistic state, i.e., the water leak at the wall of the slope. Therefore, the raising of groundwater level (at the top of slope) does not impact the FS for slip surface I. Then the FS value still remains at 1.052. It means the slope is in critical condition.

On the other hand, results show that the raising of groundwater table impact the FS for slip surface at the top of slope (Slip surface II-Figure 4). It shows that slope stability waned as rising of groundwater level. The value of safety factor is reduced by an average of 0.034 in each $0.5 \mathrm{~m}$ up of groundwater level until it become failure when the groundwater level rise up to $0.95 \mathrm{~m}$ above the actual position. Figure 6 shows the graphic of the relationship between 


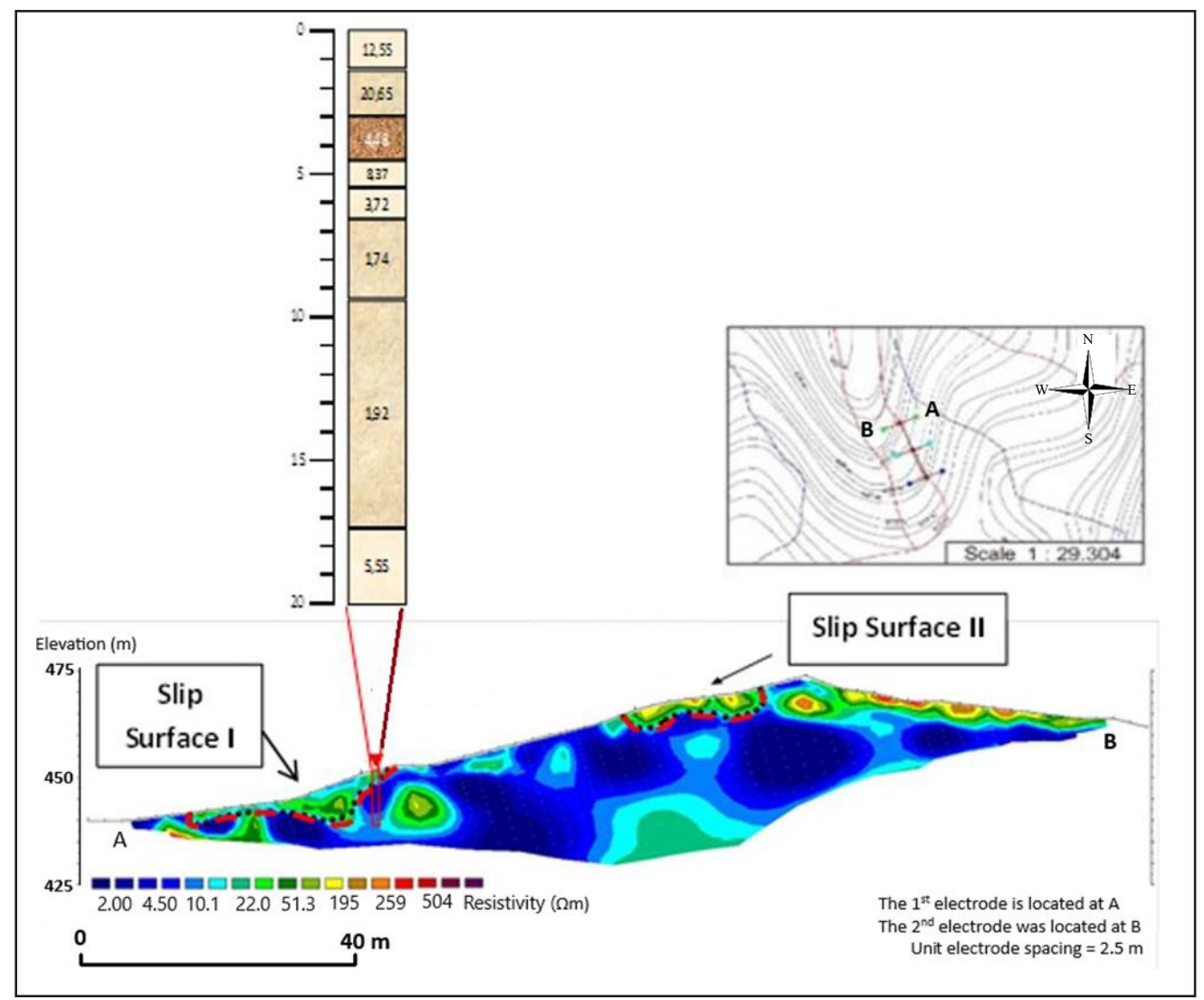

Figure 4. Slope profile generated from 3D resistivity method.

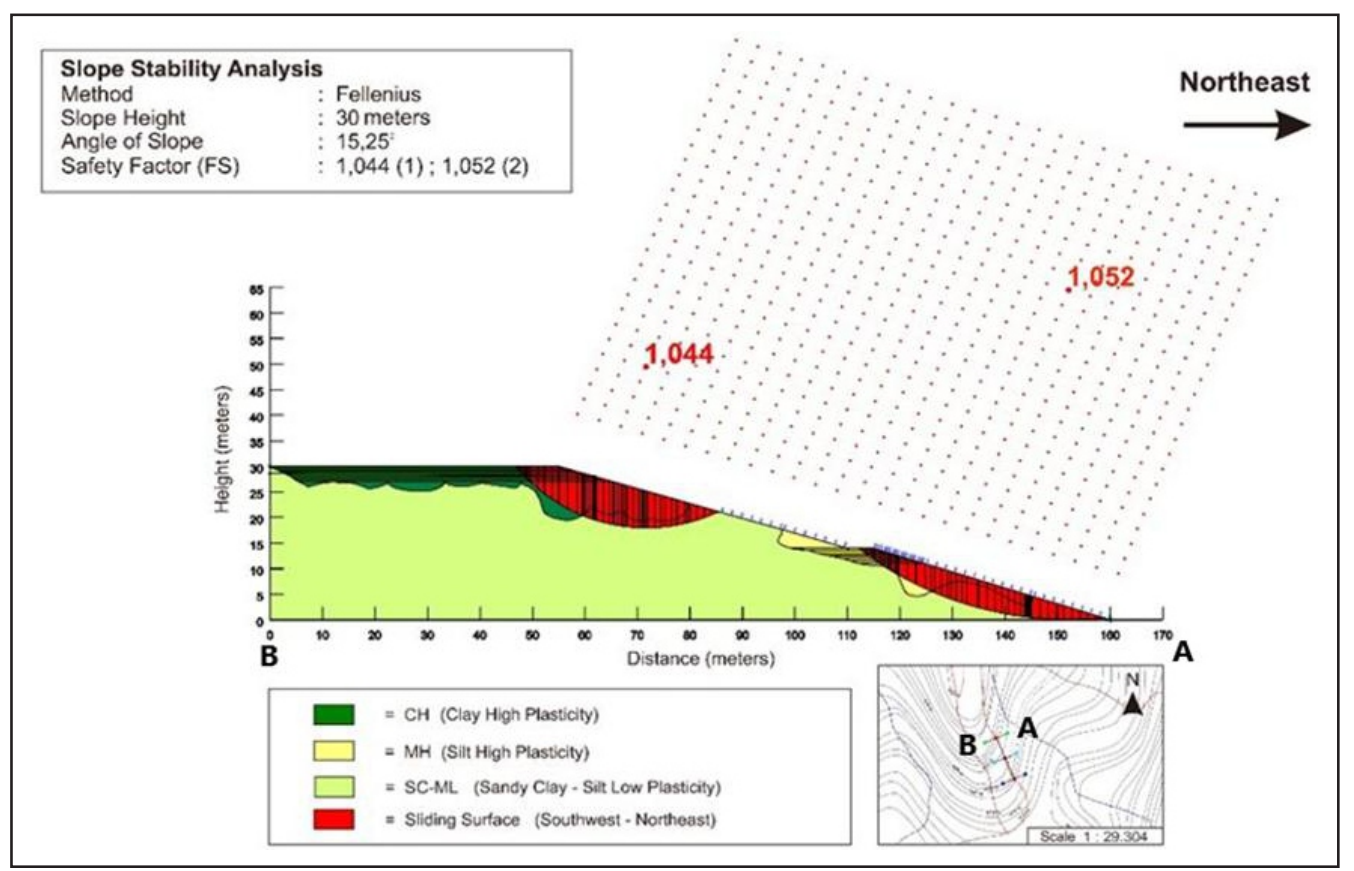

Figure 5. Slope stability profile and analysis (actual condition).

groundwater levels rising with decreasing of FS for slip surface II. It shows linear relation- ship between both of them with formula $\mathrm{y}=$ $-0.0019 x+1.038$. 


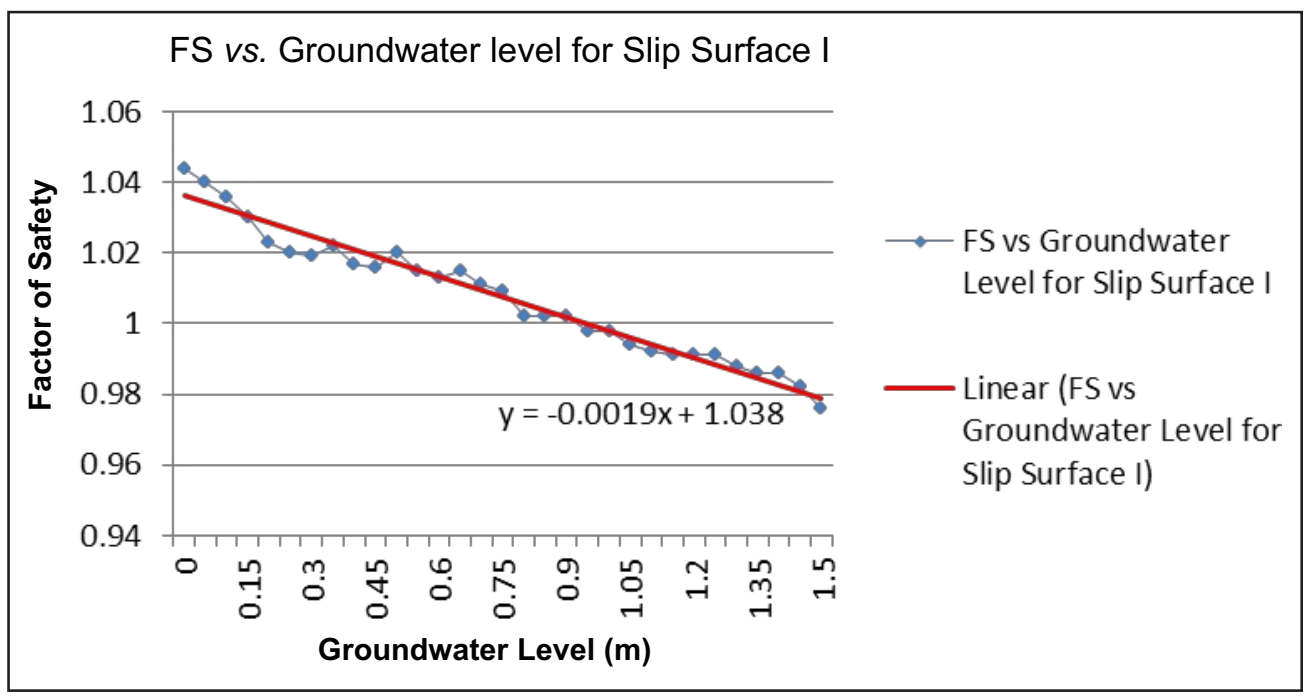

Figure 6. Relationship graphic of groundwater level rising $v s$. the value of FS.

\section{CONCLUSION}

The position of groundwater level played a role in the stability of slope in Pagelaran for slip surface I (at the top of the slope). The rising 0.5 $\mathrm{m}$ of groundwater level position will reduce the slope safety factor by 0.034 . The slope will fail if the groundwater level rises by $0.95 \mathrm{~m}$. It can be attached pipes along the slope body, and then the groundwater may flow through them, to prevent the rising of groundwater level in the rainy season, which can trigger landslides. Based on the result of the analysis that represented by the Fig. ure 6, it is also concluded that the method of ERT can help to simulate the relationship between the groundwater fluctuation and stability of the slope; especially in determining the slip surface.

\section{ACKNOWLEDGEMENTS}

The authors would like to thank the Department of Geoscience, FMIPA Universitas Indonesia and the government of Pagelaran District and Cianjur Regency for providing valuable support. This research also supported by PITTA grants provided by Universitas Indonesia.

\section{REFERENCES}

Anonymous, 2014. Landslide Vulnerability Map of Cianjur Regency, West Java. Vol- canological Survey of Indonesia (VSI), Geological Agency of Indonesia.

Anonymous, 2018. A Short Report of Landslide Emergency Response in Pagelaran District, Pagelaran Regency, West Java Indonesia, Volcanological Survey of Indonesia (VSI), Geological Agency of Indonesia. [http://www.vsi.esdm.go.id/ index.php/gerakan-tanah/kejadiangerakan-tanah/680-lapsing-gerakantanah-di-kec-pagelaran-kab-cianjurjawa-barat]

Alimohammadlou, Y., Najafi, A., and Gockceoglu, C., 2014. Estimation of RainfallInduced Landslides Using ANN and Fuzzy Clustering Methods: A Case Study in Saeen Slope, Azerbaijan Province, Iran, Catena Vol. 120, Elsevier Inc., USA. DOI: 10.1016/j.catena.2014.04.009

Asriza, Supriyanto, Kristyanto, T.H.W., Indra, T.L., Syahputra, R., and Tempessy, A.S., 2017. Determination of the Landslide Slip Surface Using Electrical Resistivity Tomography (ERT) Technique, Advancing Culture of Living with Landslides Vol. 2, Springer Link, USA. DOI: 10.1007/978-3-319-53498-5_7Bowles, J.E., 1970. Geotechnics and Physical Properties of Soil, McGraw-Hill Education - Europe, New York. 
Bui, D.T., Tuan, T.A., Klempe, H., Pradhan, B., and Revhaug, I., 2016. Spatial Prediction Models for Shallow Landslide Hazards: A Comparative Assessment of the Efficacy of Support Vector Machines, Artificial Neural Networks, Kernel Logistic Regression, and Logistic Model Tree, Landslide Vol. 13, Springer Link, USA. DOI: 10.1007/s10346-015-0557-6

Jongmans, D. and Garambois, Stéphane, 2007. Geophysical Investigation of Landslides: a review. Bulletin Société Géologique de France Vol. 178, Société géologique de France, Paris. DOI: 10.2113/gssgfbull.178.2.101

Guzzetti, F., Peruccacci, S., Rossi, M., and Stark, C.P., 2008. The Rainfall IntensityDuration Control of Shallow Landslides and Debris Flows: An Update, Landslides Vol. 5, Springer Link, USA. DOI: 10.1007/s10346-007-0112-1

Koesmono, M., Kusnama, and Suwarna, N., 1996. Geological Map of Sindangbarang and Bandarwaru, Indonesian Geological Agency, Bandung.

Liu, G., Zhuang, X., and Cui, Z., 2017. ThreeDimensional Slope Stability Analysis Using Independent Cover Based Numerical Manifold and Vector Method, Engineering Geology Volume 225, Elsevier Inc, USA. DOI: 10.1016/j.enggeo.2017.02.022
McCann, D.M. and Foster, A., 1990. Reconnaissance Geophysical Methods in Landslide Investigations, Engineering Geology Volume 29, Elsevier Inc., USA. DOI: 10.1016/0013-7952(90)90082-C

Purnamasari, D.I. and Madlazim, 2015. Analisis Korelasi Antara Magnitudo Momen Gempa Bumi Regional dengan Periode Dominan Gelombang P di Wilayah Indonesia, Jurnal Inovasi Fisika Indonesia Vol 4, No. 2, Penerbit Universitas Negeri Surabaya, Surabaya.

Ramadhika, F., Kristyanto, T.H.W., Indra, T.L., and Syahputra, R., 2018. The Responsibility of High Activity Clay Mineral Toward Landslide Occurrence in Volcanic Sediment Area, Cianjur, AIP Conference Proceedings Vol. 2023, Issue 1, AIP Publishing, USA. DOI: 10.1063/1.5064183

Salam, A.F., Kristyanto, T.H.W., Asriza, Syahputra, R., Tempessy, A.S., and Indra, T.L., 2017. Collaboration of High Activity Soil and Geological Structure Factors in Pagelaran Soil Creep Occurrence, Indonesia, MATEC Web Conf. Vol. 101, EDP Sciences, France. DOI: 10.1051/ matecconf $/ 201710104012$

Telford, W.M., Geldart, L.P., and Sheriff, E., 1990. Applied Geophysics - $2^{\text {nd }}$ edition, Press Syndicate of the University of Cambridge, New York. 